\title{
Surgical management of esophageal carcinoma
}

\author{
Amit N. Patel, MD, MS, John T. Preskitt, MD, Joseph A. Kuhn, MD, Robert F. Hebeler, MD, \\ RICHARD E. WOOD, MD, AND HAROLD C. URSCHEL, JR., MD
}

A lthough esophageal carcinoma is not the most common tumor-it accounts for only $5 \%$ of all gastrointestinal tumors and $1 \%$ of all new tumors-it has nearly a $1: 1$ mortality ratio: each year there are 14,000 new cases and 13,000 related deaths in the USA. Men have esophageal carcinoma 3 to 5 times more often than women, and black men are 3 times more likely than white men to have the disease. The mean age at diagnosis is 60 years.

\section{BACKGROUND}

Adenocarcinoma, typically in the distal third of the esophagus, and squamous cell carcinoma, typically in the proximal two thirds of the esophagus, each make up $49 \%$ of cases of esophageal cancer. The remaining cancers in this area include sarcoma $(1 \%)$, lymphoma $(0.5 \%)$, cylindroma $(0.25 \%)$, and primary melanoma $(0.25 \%)(1)$. The incidence of adenocarcinoma is clearly increasing; it will soon become the most prevalent type of cancer of the esophagus. No malignant tumor in the past 25 years has increased in incidence as much as adenocarcinoma of the esophagus. The primary risk of adenocarcinoma is related to the duration and severity of gastric-esophageal reflux and the progression of mucosal changes from Barrett's esophagus to dysplasia to adenocarcinoma. Early detection is the most important factor in determining survival. Most patients present with stage IIB to stage IV disease, and most disease occurs at the gastroesophageal junction.

Among patients with Barrett's esophagus, the risk of developing adenocarcinoma is $0.2 \%$ to $2.1 \%$ each year; $77 \%$ of patients with adenocarcinoma have had Barrett's esophagus. Endoscopy with systematic biopsy cannot reliably exclude the presence of occult adenocarcinoma, since it could miss adenocarcinoma located somewhere else in that region. Forty percent of patients with Barrett's esophagus and dysplasia have invasive carcinoma in the resected specimen.

The incidence of squamous cell carcinoma, which used to be the major cause of esophageal cancer, has significantly decreased. The decrease may be related to reductions in risk factors, which include smoking, excessive alcohol use, caustic lye injury or thermal injury, diet, obesity, achalasia, and tylosis.

Typical symptoms of esophageal cancer include difficulty swallowing, with a feeling of fullness, pressure, burning, or coughing; a feeling of both liquids and solids becoming stuck behind the sternum; indigestion; emesis; and weight loss. Many patients attribute their symptoms to heartburn and do not seek the medical care they need.

\section{STAGING}

The staging system for esophageal carcinoma and its tumor, nodal, and metastatic components appears in Table 1. While T stage has remained the same over time, N2 disease has been taken out of the system, and M1 has been divided into 2 subgroups based on the area affected.

Endoscopy and biopsy are essential for determining whether the tumor is squamous carcinoma, Barrett's esophagus, or adenocarcinoma. However, multiple staging modalities are available, from physical examination to computed tomography (CT), endoscopic ultrasound, magnetic resonance imaging (MRI), positron emission tomography (PET), thoracoscopy/laparoscopy, bone scan, laryngoscopy, and bronchoscopy.

CT scan is used most frequently in diagnosis. While it clearly shows the presence of tumor, it is only $49 \%$ to $60 \%$ accurate in staging the depth of the tumor, according to published reports (2-7). Endoscopic ultrasound is significantly better in determining $\mathrm{T}$ stage, with an accuracy ranging from $76 \%$ to $92 \%(3,4$, 6-9). While few studies have examined MRI's success in determining $\mathrm{T}$ stage, it appears to be very promising, with an accuracy rate of $96 \%$ to $100 \%$ (10).

For staging lymph nodes, CT has shown an accuracy rate of $39 \%$ to $74 \%(2,4,6-9)$; endoscopic ultrasound, $45 \%$ to $100 \%$ $(4,7,9,11-13)$; MRI, 56\% (14) and 74\% (15); and PET, 76\% (11), 84\% (16), and 87\% (17). Endoscopic ultrasound has not only shown enlargement of nodes but also has characterized specific pathologic and histologic features of carcinoma in the lymph nodes. Krasna and Luketich recently proposed a new staging technique involving combined thoracoscopy/laparoscopy with a $>90 \%$ accuracy rate for staging these cancers. Several other investigators have duplicated these results, which entails thorough and sequential nodal analysis via the thorascope around the firstand second-level lymph node basins $(16,18-20)$. A number of randomized studies have shown that about $50 \%$ of these cancers are upstaged when thoracoscopy or laparoscopy is performed after endoscopic ultrasound.

From the Departments of General Surgery (Patel, Preskitt, Kuhn) and Cardiothoracic Surgery (Hebeler, Wood, Urschel), Baylor University Medical Center, Dallas, Texas. Presented at surgical grand rounds, Baylor University Medical Center, Dallas, Texas, January 2003.

Corresponding author: Amit N. Patel, MD, MS, Department of Surgery, Baylor University Medical Center, 101 N. Brookside Drive, Suite 102, Dallas, Texas 75214 (e-mail: anpatel72@hotmail.com). 
Table 1. Staging of esophageal carcinoma*

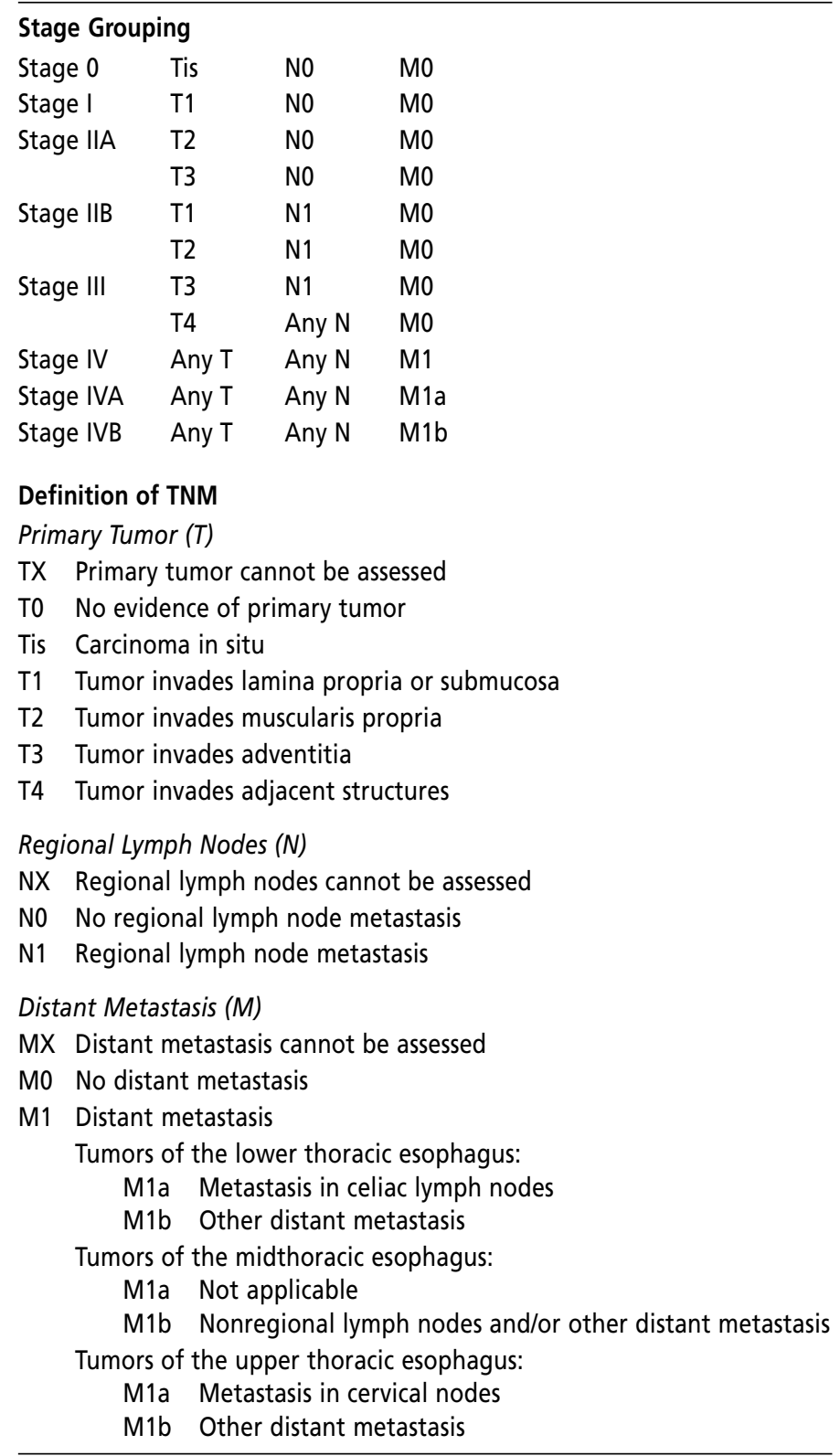

*Used with the permission of the American Joint Committee on Cancer (AJCC), Chicago, Illinois. The original source for this material is the AJCC Cancer Staging Manual, Sixth Edition (2002) published by Springer-Verlag New York, www.springer-ny.com.

The value of accurate staging is controversial. Since many patients present with an obstructing neoplasm, the clinical approach at one time involved an aggressive attempt at resection for palliation even when advanced nodal disease or metastatic disease was encountered at surgery. The advent of local ablation and nonoperative palliative management may make accurate staging more important.

\section{TREATMENT OPTIONS}

Once the disease has been staged, numerous treatment options are available. Stage 0 or I disease is usually treated with surgery alone. Stage II and III disease is often treated with surgery, with or without neoadjuvant therapy. Stage IV disease is
Table 2. Median survival duration and 3-year survival rate with and without neoadjuvant therapy for esophageal carcinoma

\begin{tabular}{lccccccc}
\hline & & \multicolumn{2}{c}{$\begin{array}{c}\text { Median survival } \\
\text { (months) }\end{array}$} & & \multicolumn{2}{c}{$\begin{array}{c}\text { 3-year survival } \\
\text { rate (\%) }\end{array}$} & \\
\cline { 7 - 8 } Trial & $\mathrm{N}$ & Surgery & Neo + surg & & Surgery & Neo + surg & P value \\
\hline Walsh (21) & 113 & 11 & 16 & & 26 & 37 & $<0.01$ \\
Law (22) & 147 & 13 & 16.8 & & 31 & 44 & NS \\
Kelsen (23) & 467 & 16.1 & 14.9 & & 37 & 35 & NS \\
Clark (24) & 802 & 13.3 & 17.2 & & 34 & 43 & NS \\
Ancona (25) & 96 & 24 & 25 & & 41 & 44 & NS \\
\hline
\end{tabular}

Neo indicates neoadjuvant chemotherapy plus radiation; surg, surgery; NS, not significant.

often treated nonsurgically, with stents, neoadjuvant therapy, photodynamic therapy, brachytherapy, or immunotherapymodalities that might help downstage the tumor in some patients.

Many studies have compared neoadjuvant chemotherapy plus radiation with radiation therapy alone. Only one study with 113 patients showed a significant improvement in the 3 -year survival rate in patients who underwent neoadjuvant chemotherapy with radiation (37\%) compared with those who underwent surgery alone $(26 \%)(P<0.01)$. However, many other studies involving over 1500 patients have not shown a similar advantage for neoadjuvant chemoradiation (Table 2).

Innovative gene therapy strategies may open the range of treatment options for esophageal cancer. Investigators at Baylor have presented data involving an adenoviral vector containing the gene for tumor necrosis factor along with a promoter region that is triggered by radiation therapy.

According to the National Cancer Institute, 39 clinical trials are currently active in the USA evaluating treatment or prevention modalities for patients with esophageal carcinoma. Some trials focus on chemoprevention with cyclooxygenase- 2 inhibitors or nonsteroidal antiinflammatory agents.

For resection, surgeons use several techniques: 1) the IvorLewis, a thoracoabdominal approach; 2) the transhiatal, involving the abdomen and neck while avoiding the thoracic incision; 3 ) the transabdominal, used particularly for cancers of the lower gastroesophageal junction; and 4) the thoracoscopic/laparoscopic, a minimally invasive approach.

After removing the esophagus, surgeons usually use the stomach to create a neoesophagus. A colon interposition is sometimes used when the stomach is not suitable. Concerns with the colon include its tenuous blood supply and the possibility of intrinsic disease. A last resort is a jejunal interposition, usually as a free graft or augmented vascular supply. Techniques for anastomosis include the traditional 2-layer hand-sewn, a single-layer absorbable hand-sewn, a stapled end-to-end, and a robot-assisted endto-end.

Beitler and Urschel's review of 4 randomized trials and 7 nonrandomized comparative studies showed that stapled and hand-sewn anastomoses have equivalent leak rates, but strictures are more common in stapled anastomoses (26). Strictures can be easily treated with serial dilation, whereas a leak can be a cata- 
Table 3. Results of esophagectomy

\begin{tabular}{lccccc}
\hline Study & Type & N & $\begin{array}{c}\text { Mortality } \\
\text { rate (\%) }\end{array}$ & $\begin{array}{c}\text { Morbidity } \\
\text { rate (\%) }\end{array}$ & $\begin{array}{c}\text { 5-year survival } \\
\text { rate (\%) }\end{array}$ \\
\hline Skinner (29) & En bloc & 80 & 11 & 52 & 18 \\
Altorki (30) & En bloc & 78 & 5 & 58 & 33 \\
Altorki (31) & En bloc & 111 & 5 & 49 & 37 \\
Orringer (32) & THE & 100 & 12 & 38 & 15 \\
Orringer (33) & THE & 1085 & 4 & 26 & 32 \\
Rao (34) & THE & 411 & 11 & 27 & 38 \\
Mannell (35) & Total & 93 & 12 & 45 & 13 \\
King (36) & RT & 100 & 3 & 27 & 15 \\
Lozac'h (37) & RT & 264 & 2 & 23 & 27 \\
\hline
\end{tabular}

THE indicates transhiatal esophagectomy; RT, right thoracotomy.

Table 4. Metaanalysis comparing types of operation for esophageal carcinoma

\begin{tabular}{|c|c|c|c|}
\hline & $\begin{array}{l}\text { Transthoracic* } \\
(\mathrm{n}=4591)\end{array}$ & $\begin{array}{c}\text { Transhiatal* } \\
(\mathrm{n}=3383)\end{array}$ & $\begin{array}{c}\text { THLAt } \\
(n=274)\end{array}$ \\
\hline ICU stay (days) & 11.2 & 9.1 & 3.6 \\
\hline Hospital stay (days) & 21.0 & 17.8 & 11.2 \\
\hline In-hospital mortality (\%) & 9.2 & 5.7 & 2.7 \\
\hline Wound infection (\%) & 7.7 & 4.3 & 1 \\
\hline Vocal cord paralysis (\%) & 3.5 & 9.5 & 0 \\
\hline 3-year survival (\%) & 27 & 25 & $58 \ddagger$ \\
\hline 5-year survival (\%) & 35.2 & 24.9 & - \\
\hline \multicolumn{4}{|c|}{$\begin{array}{l}\text { *From reference } 38 . \\
\text { †From reference } 39 \text { and other sources. } \\
\text { \$Value represents } 30 \text {-month survival rate rather than 3-year survival rate. } \\
\text { ICU indicates intensive care unit; THLA, thoracoscopy/laparoscopy. }\end{array}$} \\
\hline
\end{tabular}

strophic complication. Another metaanalysis of 9 randomized trials showed that if surgeons didn't perform a pyloric drainage procedure, the incidence of gastric outlet obstruction was significantly increased (27). However, the article did not address the fact that pyloric drainage procedures increase the risk of bile reflux; most patients with esophageal carcinoma have reflux.

\section{OUTCOMES}

One of the most important factors in surgical success is clear margins. Roder et al showed that survival duration was dramatically decreased if there was residual tumor: for example, in stage I disease, survival duration decreased from 79 months to 23 months in patients with residual tumor, and in stage IIB disease, survival duration decreased from 30 months to 6 months (28).

With all techniques, the 5 -year survival rate averages $18 \%$ to $38 \%$ (Table 3). A metaanalysis of all published literature in the English language on transthoracic, transhiatal, and thoracoscopic/laparoscopic procedures revealed that intensive care unit stay and total hospital length of stay were lower in the group treated with the transhiatal approach (Table 4). Hulscher et al followed up on their metaanalysis of transthoracic and transhiatal
Table 5. Operative mortality and morbidity rates for 61 esophageal cancer patients at Baylor University Medical Center

\begin{tabular}{lll}
\hline Complication & $\mathrm{n}$ & $\%$ \\
\hline Death & 2 & 3 \\
Anastomotic leak & 4 & 7 \\
Respiratory failure & 3 & 5 \\
Vocal cord paresis & 3 & 7 \\
Psychosis & 2 & 3 \\
Deep vein thrombosis & 1 & 2 \\
Atrial fibrillation & 2 & 3 \\
Myocardial infarction & 1 & 2 \\
Anastomotic stricture & 7 & 11 \\
Major wound infection & 0 & 0 \\
\hline
\end{tabular}

procedures with a randomized trial, which also showed that transhiatal procedures resulted in a shorter intensive care unit stay, shorter hospital stay, and lower frequency of pulmonary complications (all $P<0.001$ ) but did not have a statistically significant effect on survival (40). While the thoracoscopic/laparoscopic procedures seem to yield better short-term survival rates, most of the literature on this procedure consists of case reports. Randomized studies are needed to see whether the technique actually offers better results or the reports reflect a selection bias.

In the largest prospective outcomes cohort in the literature, Bailey et al documented a near 50\% morbidity rate and 10\% mortality rate after esophagectomy in 1700 patients of Veterans Affairs facilities. Multivariate analysis revealed that neoadjuvant chemotherapy was the risk factor that best predicted 30-day mortality. Other predictors of mortality included greater age, intraoperative transfusions, ascites, and diabetes (41).

Overall, the 5 -year survival rate is about $50 \%$ for stage I disease but drops precipitously for patients with higher-stage disease $(28,29,42,43)$. Similarly, having even 1 lymph node positive for disease decreases survival rates by $25 \%$ to $40 \%$, and having 4 or more positive nodes is associated with a survival rate of $\leq 5 \%(28,44,45)$. The 4 predictors of the worst 30 -day survival rate after surgery were positive lymph nodes, higher-stage disease, blood transfusion of $\geq 3$ units, and incomplete tumor resection (46).

\section{DISTAL ESOPHAGECTOMY EXPERIENCE AT BAYLOR}

Between 1992 and 2000, surgeons at Baylor treated 61 patients with cancer of the gastroesophageal junction. The mean age of the patients was 56 years (range 33-77); 53 of the 61 patients were men. Forty-eight had adenocarcinoma, 10 had squamous cell carcinoma, 1 had squamous cell carcinoma plus adenoma, and 2 had carcinosarcoma. Most patients had early stage disease and were thus good surgical candidates: $3(5 \%)$ had stage 0 disease; 21 (34\%), stage I; 15 (26\%), stage IIA; 7 (11\%), stage IIB; 8 (13\%), stage III; and 7 (11\%), stage IV.

Twenty-eight patients $(46 \%)$ received neoadjuvant therapy, consisting of a combination of cisplatin, 5-fluorouracil, and 45 Gy of radiation. After this therapy, 5 patients-all with squamous cell carcinoma-had a complete response in their primary tumor. 


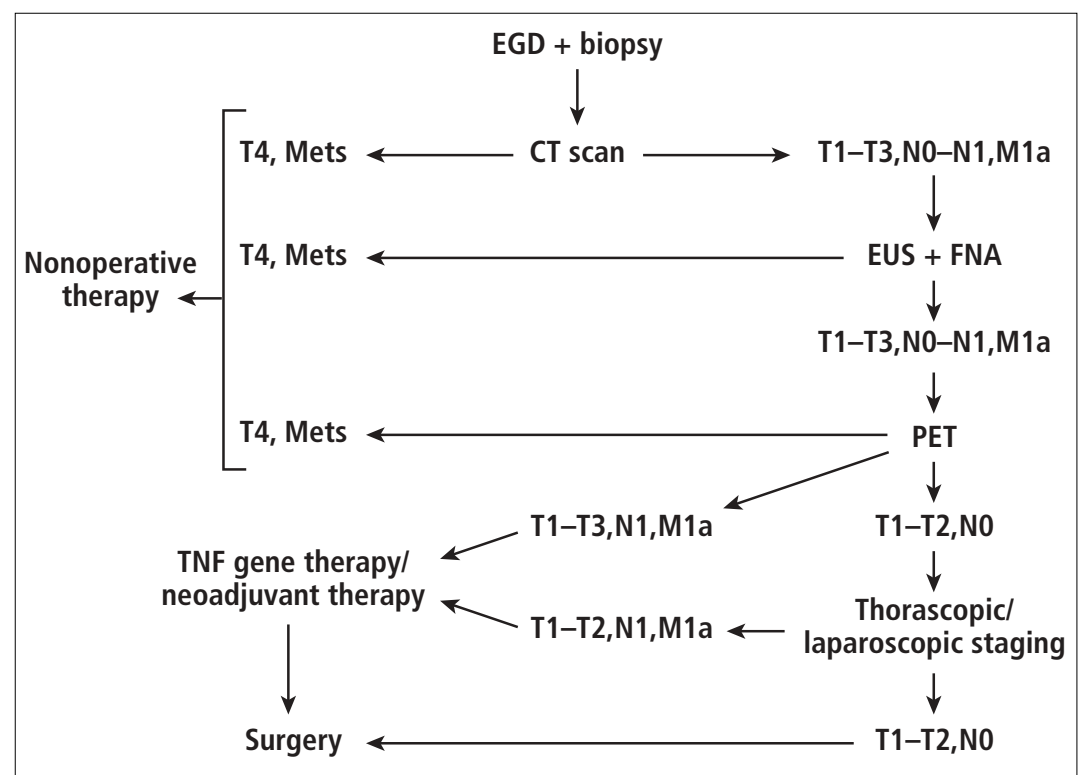

Figure. Proposed treatment algorithm for patients with esophageal carcinoma. CT indicates computed tomography; EGD, esophagogastroduodenoscopy; EUS, endoscopic ultrasound; FNA, fineneedle aspiration; mets, metastases; PET, positron emission tomography; TNF, tumor necrosis factor. For definition of TNM staging, refer to Table 1.

One of 3 procedures was used, depending on surgeon preference and patient needs (curative or palliative): 21 patients underwent the Ivor Lewis procedure; 38, the transhiatal procedure; and 2, the transabdominal procedure. The transhiatal approach was used more in the later years as its superiority in decreasing morbidity was recognized. A gastric conduit was used in 58 patients and a colon interposition in 3 patients. The complications of vocal cord paralysis and stricture were all associated with transhiatal esophagectomies. The complications of anastomotic leak and respiratory failure occurred with the Ivor-Lewis procedure. Two patients died within 30 days of this operation; both were severely ill (Table 5).

After follow-up intervals ranging from 3 months to 8 years (mean 5 years), the 5 -year age-matched expected survival rate was $87 \%$. Our actual observed survival rates were $66 \%$ for carcinoma and 100\% for dysplasia/high-grade Barrett's esophagus.

\section{SUMMARY AND PROPOSED TREATMENT ALGORITHM}

Some summary points from the review are as follows:

- In tumor staging, endoscopic ultrasound and/or MRI are both more accurate than CT scan.

- In nodal staging, the thoracoscopic/laparoscopic approach has been found to be more accurate than endoscopic ultrasound, which is better than PET scan, MRI, and CT scan.

- Neoadjuvant therapy is still investigational. While it may have a role in downstaging - several studies showed a 30\% to $40 \%$ downstaging success rate-it has increased morbidity rates both intraoperatively and postoperatively and causes patient dropout from protocol due to the toxicities of the therapy.

- The hand-sewn anastomosis technique leads to more leaks, while stapled anastomosis leads to more strictures.

- If pyloric drainage is not performed, there is a significant risk of gastric outlet obstruction, which is counteracted by the risk of having chronic bile reflux.
- There is no difference in survival rates between the transthoracic and transhiatal approaches. Thoracoscopy/laparoscopy appears to yield better survival statistics, but more study is required. Based on the analysis and our data, a standardization of therapy is proposed (Figure). Upon diagnosis with esophagogastroduodenoscopy with biopsy, the patient would undergo a CT scan, mainly to look for distant metastases. If the CT scan showed that the cancer was stage I through III, the patient would undergo endoscopic ultrasound with fine-needle aspiration. Any time stage IV disease was diagnosed, the patient would receive nonoperative therapy. PET scans and thoracoscopic/laparoscopic staging would be used to further determine if tumor necrosis factor gene therapy or neoadjuvant therapy were needed to downstage the tumor before proceeding to surgery for a curative or palliative operation.

1. American Cancer Society. Cancer Facts and Figures 2003. Atlanta, Ga: American Cancer Society, 2003.

2. Massari M, Cioffi U, De Simone M, Lattuada E, Montorsi M, Segalin A, Bonavina L. Endoscopic ultrasonography for preoperative staging of esophageal carcinoma. Surg Laparosc Endosc 1997;7:162165.

3. Hordijk ML, Zander $\mathrm{H}$, van Blankenstein M, Tilanus HW. Influence of tumor stenosis on the accuracy of endosonography in preoperative $\mathrm{T}$ staging of esophageal cancer. Endoscopy 1993;25:171-175.

4. Nattermann C, Dancygier H. [Endoscopic ultrasound in preoperative TN staging of esophageal cancer. A comparative study between endosonography and computerized tomography.] Ultraschall Med 1993;14:100-105.

5. Kalantzis N, Kallimanis G, Laoudi F, et al. Endoscopic ultrasonography and computed tomography in preoperative (TNM) classification of oesophageal carcinoma [abstract]. Endoscopy 1992;24:653A.

6. Ziegler K, Sanft C, Zeitz M, Friedrich M, Stein H, Haring R, Riecken EO. Evaluation of endosonography in TN staging of oesophageal cancer. Gut 1991;32:16-20.

7. Tio TL, Cohen P, Coene PP, Udding J, den Hartog Jager FC, Tytgat GN. Endosonography and computed tomography of esophageal carcinoma. Preoperative classification compared to the new (1987) TNM system. Gastroenterology 1989;96:1478-1486.

8. Fekete F, Sauvanet A, Zins M, Berthoux L, Amouyal G. [Imaging of cancer of the esophagus: ultrasound-endoscopy or computed tomography? Ann Chir 1995;49:573-578.

9. Botet JF, Lightdale CJ, Zauber AG, Gerdes H, Urmacher C, Brennan MF. Preoperative staging of esophageal cancer: comparison of endoscopic US and dynamic CT. Radiology 1991;181:419-425.

10. Yamada I, Murata Y, Izumi Y, Kawano T, Endo M, Kuroiwa T, Shibuya H. Staging of esophageal carcinoma in vitro with 4.7-T MR imaging. Radiology 1997;204:521-526.

11. Flanagan FL, Dehdashti F, Siegel BA, Trask DD, Sundaresan SR, Patterson GA, Cooper JD. Staging of esophageal cancer with ${ }^{18} \mathrm{~F}$-fluorodeoxyglucose positron emission tomography. AJR Am J Roentgenol 1997;168:417-424.

12. Luketich JD, Schauer P, Landreneau R, Nguyen N, Urso K, Ferson P, Keenan R, Kim R. Minimally invasive surgical staging is superior to endoscopic ultrasound in detecting lymph node metastases in esophageal cancer. J Thorac Cardiovasc Surg 1997;114:817-821.

13. Catalano MF, Sivak MV Jr, Rice T, Gragg LA, Van Dam J. Endosonographic features predictive of lymph node metastasis. Gastrointest Endosc 1994 40:442-446.

14. Ariga T. [Diagnosis of lymph node metastasis in esophageal carcinoma: detecting with coronal magnetic resonance imaging.] Nippon Geka Gakkai Zasshi 1990;91:797-807.

15. Petrillo R, Balzarini L, Bidoli P, Ceglia E, D’Ippolito G, Tess JD, Musumeci 
R. Esophageal squamous cell carcinoma: MRI evaluation of mediastinum. Gastrointest Radiol 1990;15:275-278.

16. Luketich JD, Friedman DM, Weigel TL, Meehan MA, Keenan RJ, Townsend DW, Meltzer CC. Evaluation of distant metastases in esophageal cancer: 100 consecutive positron emission tomography scans. Ann Thorac Surg 1999;68:1133-1136.

17. Flamen P, Lerut A, Van Cutsem E, Cambier JP, Maes A, De Wever W, Peeters M, De Leyn P, Van Raemdonck D, Mortelmans L. The utility of positron emission tomography for the diagnosis and staging of recurrent esophageal cancer. J Thorac Cardiovasc Surg 2000;120:1085-1092.

18. Krasna MJ, Reed CE, Nedzwiecki D, Hollis DR, Luketich JD, DeCamp MM, Mayer RJ, Sugarbaker DJ. CALGB 9380: a prospective trial of the feasibility of thoracoscopy/laparoscopy in staging esophageal cancer. Ann Thorac Surg 2001;71:1073-1079.

19. Krasna MJ. The role of thoracoscopic lymph node staging in esophageal cancer. Int Surg 1997;82:7-11.

20. Krasna MJ, Flowers JL, Attar S, McLaughlin J. Combined thoracoscopic/ laparoscopic staging of esophageal cancer. J Thorac Cardiovasc Surg 1996; 111:800-806.

21. Walsh TN, Noonan N, Hollywood D, Kelly A, Keeling N, Hennessy TP. A comparison of multimodal therapy and surgery for esophageal adenocarcinoma. N Engl J Med 1996;335:462-467.

22. Law S, Fok M, Chow S, Chu KM, Wong J. Preoperative chemotherapy versus surgical therapy alone for squamous cell carcinoma of the esophagus: a prospective randomized trial. J Thorac Cardiovasc Surg 1997;114:210 217.

23. Kelsen DP, Ginsberg R, Pajak TF, Sheahan DG, Gunderson L, Mortimer J, Estes N, Haller DG, Ajani J, Kocha W, Minsky BD, Roth JA. Chemotherapy followed by surgery compared with surgery alone for localized esophageal cancer. N Engl J Med 1998;339:1979-1984.

24. Clark P. Chemotherapy in oesophageal cancer. Clin Oncol (R Coll Radiol) 2001;13:155-156.

25. Ancona E, Ruol A, Santi S, Merigliano S, Sileni VC, Koussis H, Zaninotto G, Bonavina L, Peracchia A. Only pathologic complete response to neoadjuvant chemotherapy improves significantly the long term survival of patients with resectable esophageal squamous cell carcinoma: final report of a randomized, controlled trial of preoperative chemotherapy versus surgery alone. Cancer 2001;91:2165-2174.

26. Beitler AL, Urschel JD. Comparison of stapled and hand-sewn esophagogastric anastomoses. Am J Surg 1998;175:337-340.

27. Urschel JD, Blewett CJ, Young JE, Miller JD, Bennett WF. Pyloric drainage (pyloroplasty) or no drainage in gastric reconstruction after esophagectomy: a meta-analysis of randomized controlled trials. Dig Surg 2002; 19:160-164.

28. Roder JD, Busch R, Stein HJ, Fink U, Siewert JR. Ratio of invaded to removed lymph nodes as a predictor of survival in squamous cell carcinoma of the oesophagus. Br J Surg 1994;81:410-413.

29. Skinner DB. En bloc resection for neoplasms of the esophagus and cardia. J Thorac Cardiovasc Surg 1983;85:59-71.
30. Altorki NK, Girardi L, Skinner DB. En bloc esophagectomy improves survival for stage III esophageal cancer. J Thorac Cardiovasc Surg 1997;114:948955.

31. Altorki N, Skinner D. Should en bloc esophagectomy be the standard of care for esophageal carcinoma? Ann Surg 2001;234:581-587.

32. Orringer MB. Transhiatal esophagectomy without thoracotomy for carcinoma of the thoracic esophagus. Ann Surg 1984;200:282-288.

33. Orringer MB, Marshall B, Iannettoni MD. Transhiatal esophagectomy for treatment of benign and malignant esophageal disease. World J Surg 2001; 25:196-203.

34. Rao YG, Pal S, Pande GK, Sahni P, Chattopadhyay TK. Transhiatal esophagectomy for benign and malignant conditions. Am J Surg 2002;184:136-142.

35. Mannell A, Becker PJ, Nissenbaum M. Bypass surgery for unresectable oesophageal cancer: early and late results in 124 cases. Br J Surg 1988;75:283286.

36. King RM, Pairolero PC, Trastek VF, Payne WS, Bernatz PE. Ivor Lewis esophagogastrectomy for carcinoma of the esophagus: early and late functional results. Ann Thorac Surg 1987;44:119-122.

37. Lozac'h P, Topart P, Khoury-Helou A, Volant A, De Tinteniac A. [Ivor Lewis surgical procedure for epidermoid cancer of the esophagus. Apropos of 264 cases]. J Chir (Paris) 1997;134:349-356.

38. Hulscher JB, Tijssen JG, Obertop H, van Lanschot JJ. Transthoracic versus transhiatal resection for carcinoma of the esophagus: a meta-analysis. Ann Thorac Surg 2001;72:306-313.

39. Litle VR, Buenaventura PO, Luketich JD. Minimally invasive resection for esophageal cancer. Surg Clin North Am 2002;82:711-728.

40. Hulscher JB, van Sandick JW, de Boer AG, Wijnhoven BP, Tijssen JG, Fockens P, Stalmeier PF, ten Kate FJ, van Dekken H, Obertop H, Tilanus HW, van Lanschot JJ. Extended transthoracic resection compared with limited transhiatal resection for adenocarcinoma of the esophagus. N Engl J Med 2002;347:1662-1669.

41. Bailey SH, Bull DA, Harpole DH, Rentz JJ, Neumayer LA, Pappas TN, Daley J, Henderson WG, Krasnicka B, Khuri SF. Outcomes after esophagectomy: a ten-year prospective cohort. Ann Thorac Surg 2003;75:217-222.

42. Killinger WA Jr, Rice TW, Adelstein DJ, Medendorp SV, Zuccaro G, Kirby TJ, Goldblum JR. Stage II esophageal carcinoma: the significance of T and N. J Thorac Cardiovasc Surg 1996;111:935-940.

43. Ellis FH Jr, Heatley GJ, Balogh K. Proposal for improved staging criteria for carcinoma of the esophagus and cardia. Eur J Cardiothorac Surg 1997; 12:361-364.

44. Korst RJ, Rusch VW, Venkatraman E, Bains MS, Burt ME, Downey RJ, Ginsberg RJ. Proposed revision of the staging classification for esophageal cancer. J Thorac Cardiovasc Surg 1998;115:660-669.

45. Kawahara K, Maekawa T, Okabayashi K, Shiraishi T, Yoshinaga Y, Yoneda S, Hideshima T, Shirakusa T. The number of lymph node metastases influences survival in esophageal cancer. J Surg Oncol 1998;67:160-163.

46. Langley SM, Alexiou C, Bailey DH, Weeden DF. The influence of perioperative blood transfusion on survival after esophageal resection for carcinoma. Ann Thorac Surg 2002;73:1704-1709. 